\title{
More Value of Maroua Clay in the Formulation of Ceramic Products (Terracotta, Earthenware, Stoneware, Porcelain)
}

\author{
B. Touogam Touolak ${ }^{1}$, F. Tchangnwa Nya ${ }^{1,2^{*}}$ \\ ${ }^{1}$ Department of Materiel Processing, Architecture and Habitat, Higher Institute of the Sahel, Maroua, Cameroon \\ ${ }^{2}$ Department of Physics, Faculty of Sciences, University of Maroua, Maroua, Cameroon \\ Email: "nyafridolin@yahoo.fr
}

Received 15 October 2014; revised 2 December 2014; accepted 14 December 2014

Copyright (C) 2014 by authors and Scientific Research Publishing Inc.

This work is licensed under the Creative Commons Attribution International License (CC BY). http://creativecommons.org/licenses/by/4.0/

(c) () Op Open Access

\section{Abstract}

As a part of the framework of the development of ceramic products, scientific research continues this idea that clays are essential vehicles for local development in Africa; and therefore they deserve to be made profitable. This scientific work has the advantage of providing a solution to the housing of the Sahel area. On the other hand, this study can effectively serve as the basis of data in the formulation of ceramics from clay Maroua, in the region of the Far North Cameroon, for a large-scale industrial operation. Thus, two samples of materials respectively K01 and IP2 have been the subject of a preliminary chemical and mineralogical size rheological study. Once formed, the tubes containing the $\mathrm{KO1}$ and PI2 materials have undergone heat treatment at successive temperatures of $900^{\circ} \mathrm{C}, 1000^{\circ} \mathrm{C}$ and $1100^{\circ} \mathrm{C}$. The baked products obtained have also been the subject of a study of resonance, coloring density, loss on ignition, water absorption, linear shrinkage, porosity and mechanical compression.

\section{Keywords}

Clay, Formulation, Ceramic Materials, More Value, Maroua

\section{Introduction}

The studies conducted so far by the MIPROMALO have identified fifty clay bricks and baked for clues on the

*Corresponding author.

How to cite this paper: Touogam Touolak, B. and Tchangnwa Nya, F. (2014) More Value of Maroua Clay in the Formulation of Ceramic Products (Terracotta, Earthenware, Stoneware, Porcelain). Advances in Materials Physics and Chemistry, 4, 284-299. http://dx.doi.org/10.4236/ampc.2014.412031 
territory tiles. Clay also stands as the most abundant material in the earth's crust and is so far largely transformed by the traditional way in our country. A number of studies have already been carried out on the clay materials and Cameroon showed that it is the important seat deposit materials based on kaolinite, illite, smectite and feldspars with excellent applications as refractories, tiles, pottery, terracotta bricks, toilets, etc. [1]-[10]. Ceramics are imported, however, this situation can be explained by underutilisation of clay materials which until now, is an artisanal way. In addition, the lack of a true local industry and a poor estimate of the potential local resources may be one reason. Do not omit the complete ignorance of the features on clay materials, which are a major obstacle to any possible project for the formulation and production of bricks, tiles, stoneware and porcelain large scale. Joining this vein, this study undertakes to provide a solution to concerns. The main objective is the ceramics formulation from clay materials from the town of Maroua. Specifically, it is within the scope of this study to conduct a physico-chemical and mineralogical characterisation of clay. Then it will analyse the issue of cooking products, and finally study the mechanical properties of the latter, for a gain optimal technology [11] [12].

\section{Behaviour of a Clay Cooking}

We will distinguish three clay based on their behaviour in groups cooking: refractory clay; the batch clay and fuse clay [13]-[15].

\subsection{Refractory Clay}

Refractory clay is used in high temperature processes. Their composition is rich in alumina. Kaolin is the most refractory of this clay. Always purified contain little quartz, usually less than $2 \%$ alkali oxide combined form and a small amount of mica. Plasticity is provided by the kaolinite and optionally, by a few spectate or hallosite. Very poor in colouring elements, they are particularly suitable for the preparation of white shard products [16].

\subsection{The Batch Clay}

They are usually coloured, used for the remarkable plasticity of their dough. They are composed of very fine par ticles, clay particles, organic matter, iron oxide and titanium oxide, mica and illite impurity feldspars. This clay are also characterised by a high content of free silica: sand can represent up to $35 \%$ dry matter mass. The product called "Ball Clay" is widely used for its plasticity and its particularly low mica. Although containing the same as kaolin clay mineral, the clay has a much higher plasticity due to the much smaller particles of kaolinite size [16].

\subsection{Fuse Clay}

Fuse natural clay are a mixtures of complex composition. They generally contain kaolinite, illite, or other alkalirich clay, sand, mica, goethite $(\mathrm{FeO}(\mathrm{OH}))$ or hematite $\left(\mathrm{Fe}_{2} \mathrm{O}_{3}\right)$, organics and very often, calcium compounds. These as micas and other alkali-rich compounds, can lower the firing temperature of the ceramic [16].

\section{Ceramic Products}

Ceramic materials are synthetic materials predominantly consisting essentially of inorganic phase iono-covalent bonds, and generally not totally glassy consolidated by sintering at elevated temperature [17].

\subsection{General Properties of Ceramics}

The fragile nature of the clay is the major feature that determines preparation techniques and also uses of ceramics. Frailty is a hydra (evil breeds) to many heads as it involves: a lack of ductility and plasticity; low toughness and thus very sensitive to the notch effect; poor resistance to thermal shock, poor resistance to resilience; vulnerability to differential expansion so vulnerability to thermal shock; a tensile strength substantially less than the compressive strength; a significant dispersion of mechanical strength of samples deemed identical [15]. But disability is accompanied by a set of qualities that make ceramic irreplaceable for countless applications: Very good resistance to corrosion; poor conductors of heat (silicate ceramics); poor conductor of electricity; high melting temperature; high stiffness [18]-[20]. 


\subsection{Ceramic Typology}

Based on criteria taking into account mainly the open and/or porosity of the ceramic colour, it is customary to distinguish among silicate ceramics, clay products, earthenware, stoneware, porcelain and the vitreous.

\subsubsection{Traditional Ceramic or Ceramic Silicate}

This is pottery or building products such as tiles, bricks, and flues or pipes towing tile flooring. Long obtained by modeling, drying and firing of clay, but nowadays, the compositions are more complex. They mix the clay and additives. The raw materials are added to water with a plastic dough rheology must be adjusted to the method of shaping. Drying of raw parts is made or broken cell dryer. The cooking end temperature is between $900^{\circ} \mathrm{C}$ to $1160^{\circ} \mathrm{C}$. The clay products are porous and mechanically strong. They are appreciated for their aesthetic, their hygrothermal and acoustic properties [21]-[24].

\subsubsection{Earthenware}

Called faience ceramic products made of a porous ceramic material coated with glaze. This enamel to hide the appearance of the ceramic and to address the high permeability due to the existence of an open porosity of between $5 \%$ and $20 \%$. Although present as an object of fantasy and crockery, earthenware tiles are mainly used as wall covering. These products are prepared from one or more clay added quartz, chalk, feldspar or glass frit [14] [15] the tiles are essentially shaped by slip casting, sizing plastic dough and pressing atomised powder. After drying, the raw product is subjected to a heat treatment called bisque carried out at a temperature between $900^{\circ} \mathrm{C}$ and $1230^{\circ} \mathrm{C}$. Deformation and removal of the shard during this stage are limited because of the very nature of refractory raw materials [25]-[28].

\subsubsection{Ceramic Stoneware}

Stoneware ceramics are glazed shard, opaque, coloured and virtually impermeable ( $3 \%$ open porosity). They are obtained from a mixture of ball clay and flux grantee sometimes supplemented by sand or chayote. Their shaping is performed by extrusion (pipes, bricks, etc.). The firing temperature is generally between $1120^{\circ} \mathrm{C}$ and $1300^{\circ} \mathrm{C}$, it is a critical parameter. Indeed, a sintering temperature leads to an insufficient persistence of significant porosity. And a treatment at a too high temperature leads to the deformation of the parts due to too large amount of liquid formed. If the use requires, sandstone may be a baking [29]-[31]. The sandstones are known for their inalterability's their excellent mechanical performance and resistance to erosion and chemical agents. Are distinguished: chayote stoneware, compounds or fine sandstone, natural sandstone and sandstone creams [17] [18].

\subsubsection{China}

Due to the raw material used, the shards of porcelain are white and translucent in thin. They have no open, but may present some large porosity closed pores. Their break is bright and glassy in appearance. After glazing, the surface of the parts is remarkably smooth and shiny [32] [33].

\subsubsection{Vitreous}

Used especially for making sanitary ware and robust dishes. The vitreous is the transition between the sandstone and porcelain white pasta. The bathrooms are usually glazed and glazed in a single treatment, between $1200^{\circ} \mathrm{C}$ and $1280^{\circ} \mathrm{C}[17][18]$.

\section{Field Work}

Based on the analysis of the available documentation, the sampling sites of clay minerals have been identified in the vicinity of Maroua. On the ground, the work consisted of mapping sampling sites, the lithostratigraphic description of argillaceous rocks, fairly representative of the different clay lithofacies sampling, manual auger drilling or wells to obtain samples little or no altered and finally geo-environmental observations sampling sites.

\subsection{Sampling Sites of Clay Materials}

Table 1 gives an overview of the deposits of clay materials inventoried in the town of Maroua. 
Table 1. Sampling sites of clay materials.

\begin{tabular}{cccc}
\hline Well sample & Sites & Code & Geographical coordinates \\
\hline Kongola & 1 & KO1 & $10^{\circ} 37^{\prime} 0^{\prime \prime}$ Nord and $14^{\circ} 24^{\prime} 0^{\prime \prime}$ Est \\
Pitoaré & 2 & PI2 & $10^{\circ} 35^{\prime} 43.3^{\prime \prime}$ Nord and $14^{\circ} 18^{\prime} 52.8^{\prime \prime}$ Est \\
\hline
\end{tabular}

Sampling was carried out on different sites at very different depths. For this, two samples of material were taken in the town of Maroua. This is especially KO1 and IP2. The sampling took place in the open, with manual extraction equipment. As a result, the samples were stored in plastic bags to prevent temperature changes and different weather.

\subsection{Materials}

In our study, natural materials from around Maroua. These materials were chosen because of their abundance, their qualities but also their reputations; can be used as raw material in the ceramic industry [10]. Concerning laboratory equipment, physical tests are performed in the laboratory of Soil and Water Yaoundé; while the chemical and mineralogical analyses are carried out within a research team from the MIPROMALO Yaoundé and Douala LABOGENIE.

\subsection{Methods}

After sampling, we conduct an identification of the mud, and a particle size analysis (dry sieving sedimentometry). Then place the Atterberg limits of determination, followed by chemical and mineralogical analysis of clay materials.

\subsubsection{Identification of Raw Land}

A range of summary trials may allow us to assess the quality of land. These include:

The smell test: a large concentration of humus is betrayed by a smell "musty" odour characteristic of organic soils.

Test touch: a land with a high proportion of sand has no cohesion. It gives a strong feeling of roughness when it crumbles between the two palms. By silty soil against palms gives an impression of low roughness. And clay is smooth and floury, creamy and sticky if it is wet.

Test brilliance: a paste of ground homogenised and cut with a knife gives a dull appearance if it is low in clay, and is shiny if it is clay.

Adhesion test: a knife penetrates easily into clay slurry and then adhering the slurry that is otherwise for pasta silty sand.

Sedimentation test: based on the principle of washing and sedimentation of a volume of material in 3 volumes of washing water, this test is used to determine the proportions of the various constituents of the soil.

Shrinkage test: removing a plastic paste placed in a mold with smooth walls and left to dry in the sun for 3 days or 7 days in the shade mud is measured. The withdrawal is measured in $\mathrm{cm}$ gives an idea of the content of the soil clay [21]-[28] [34].

\subsubsection{The Particle Size Analysis}

Particle size analysis was done in two stages: particle size analysis by dry sieving and particle size analysis by sedimentometry.

\section{1) Particle size analysis by dry sieving}

The purpose of particle size analysis by sieving is to know the distribution of the particles of size greater than or equal to 80 microns. The aim of the test is to draw the grading curve which illustrates the evolution of the weight percentages amiss of (or refusal) accumulated based openings mesh sieve. The idea is to split it into several categories of soil grains (or particles) of decreasing dimensions through a sieve stack manually finally get a better screening and have the best results when calculating different percentages. The apparatus consists of a column of standardised sieve opening, a vibrio-sieve trays, a precision balance sensitive to centigram, a thermostat oven, and a wire brush [5] [6] [21]-[24]. 


\section{2) Particle size analysis by sedimentometry}

It is used to determine the distribution of the particles of a soil of which the largest dimension is 80 microns. It complements the size sieve analysis, and can find the full size curve. Sedimentometry involves measuring the density of a solid immersed in water suspension according to the sedimentation rate of the particles. The principle is based on the sedimentometry Stokes law which expresses, from equilibrium, the relationship between the settling speed and the diameter of a spherical particle supposed [5] [8].

\subsubsection{Atterberg Limits}

Is determined by this test the limits of liquidity and plasticity of a soil. It is realised on the floor portion of 400 $\mu \mathrm{m}$ sieving. Atterberg limits are geotechnical parameters to identify and characterise its ground state. The transition from the solid state with withdrawal in the plastic state is the plastic limit WP noted. The transition from plastic to liquid state corresponds to the liquid limit WL noted. The difference between the liquid limit and plasticity defined plasticity index that provides information on the extent of the plastic field soil [7] [35]-[37].

\subsubsection{Chemical Analysis}

It is here by XRF is caused by various forms of excitation other than the light emitting heat (sometimes called "cold light”). It can be used to characterise, among other material. The principle is the following: when a photon encounters an atom X, it has a chance to eject an electron from heart by photoelectric effect. The atom is then in an excited state. The excitation is done by an electronic transition: an electron from a higher level "down" to fill the vacuum quantum box. This transition causes the electron emission of an X-ray photon that is the X-ray fluorescence energy level being the electronic characteristics of atoms, the energy of the photon will be. In analysing the issue of a sample after irradiation spectrum, we will be able to identify the elements it contains and taking the necessary precautions to determine their concentration [35]-[38].

\subsubsection{Mineralogical Analysis}

This test is performed by X-ray diffraction (XRD). X-rays, such as light, are electromagnetic radiation. When electromagnetic radiation encounters a charged particle such as an electron, it induces a periodic movement of the electrical charge. In the case of an encounter with an atom, it is all the electrons surrounding the atom coming into oscillation. Each atom of a crystal is the center of a spherical wave whose intensity is proportional to the number of electrons. These are spherical waves interfering with each other, that is to say, their intensity is increasing in certain directions of space and cancels in other directions each. It is this constructive and destructive interference between the spherical waves that are at the origin of the phenomenon of X-ray diffraction by the crystal [25]-[28] [38].

\section{Formulating Ceramic Products}

Various formulations for the synthesis of ceramic products are made by varying the content of feldspar from $0 \%$ to $30 \%$, to a range of $10 \%$ from the masses of dry powders. Feldspars contents are respectively $10 \%, 20 \%$, and $30 \%$. The various mixtures were then moistened with distilled water until the plastic limit of water, and the shaping is carried out in molds and disk-shaped cylinder. After this processing the specimens are dried in the open air inside the laboratory for 24 hours for 48 hours and hard rolls. Should then continue drying in the oven set at $105^{\circ} \mathrm{C}$ for hard to directly observe a change in size and weight of less than $0.1 \%$. And then the cylinders with a change in temperature to $105^{\circ} \mathrm{C}$. The samples of each formulation formed after drying, are heat-treated in a programmable oven for four cleaning temperatures: $900^{\circ} \mathrm{C}, 1000^{\circ} \mathrm{C}, 1100^{\circ} \mathrm{C}, 1200^{\circ} \mathrm{C}$. The rate of temperature rise is $5^{\circ} \mathrm{C} / \mathrm{min}$ and the bearing for two (02) hours for each temperature studied. Figure 1 clearly shows the distribution of sample temperature and percentage of additive in the mixture [25]-[28] [39]-[41].

\subsection{Shaping}

For making disks, we use a mixture of $20 \%$ water to KO1 $0 \%$ and $10 \%$ builder, we also use $18 \%$ water and $30 \%$ to $20 \%$ builder. PI 2 concerning the sample, we use $20 \%$ of water and $0 \%$ to $10 \%$ builder; $18 \%$ water and $15 \%$ respectively $20 \%$ and $30 \%$ for adjuvant. For each disk we used $20 \mathrm{~g}$ of mixture. For making solid cylinders we use $180 \mathrm{~g}$ mixing. 


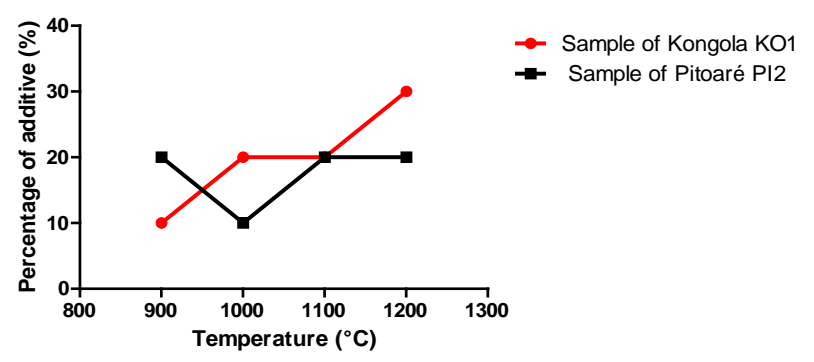

Figure 1. Distribution of sample temperature and percentage of additive in the mixture.

\subsection{Grinding Materials}

Clay materials are first crushed, and then passed through a sieve full of $315 \mu \mathrm{m}$. Regarding the laboratory grinder we used a wood crusher.

\subsection{Mixing the Materials}

The clay material is mixed with the adjuvant at different concentrations $(0 \%, 10 \%, 20 \%, 30 \%)$ dry first, then, is gradually added to a specific volume of distilled water. The percentages of water used varied between $15 \%$ and $20 \%$.

\subsection{Manufacturing or Molding of Specimens}

After mixing the material is the molding phase. The moistened mixture is filled into the mold steel on a horizontal support, by exerting manual pressure. The proceeds are subsequently removed from the mold and the specimens obtained are deposited in a location where they are dried at room temperature for a period of 48 hours.

\subsection{Drying}

This phase takes place in two (02) steps. Whether for discs or cylinders. After shaping, the specimens in the open air are allowed inside the laboratory for 48 hours. Then these specimens were placed in an oven set at $105^{\circ} \mathrm{C}$ for 24 hours.

\subsection{Baking}

This is the phase of the heat treatment allowing the agglomeration between particles, leading to a new product. Cooking is a cycle in three stages: the rise in temperature controlled, followed by maintaining the temperature to a certain value and finally, the gradual cooling to room temperature [5] [6]. The specimens were processed in the laboratory of Yaoundé MIPROMALO temperatures of $900^{\circ} \mathrm{C}, 1000^{\circ} \mathrm{C}, 1100^{\circ} \mathrm{C}$ and $1200^{\circ} \mathrm{C}$ according to the following program: temperature rise of $5^{\circ} \mathrm{C} / \mathrm{min}$ and held the bearing temperature and cook for two (02) hours [39]-[41].

\section{Analysis Curatives}

1) Water Absorption

It gives the material by the moisture over a long period taken. The specimens were dipped in a water bath for six (06) hours of time; the amount of water absorbed is measured. The goal is to determine the amount of water absorbed by the sample as a function of the increase of the firing temperature [5] [6].

2) Percentage of Pore Space

The specimen is placed in cold water and then boiled for two (02) hours of time in order to remove air from the pores and saturate with water. Finally, the new weight of the sample is measured [5] [6].

3) Loss on Ignition

The loss on ignition (LOI), expressed as a percentage, is the weight loss of a sample after calcination, based on the initial weight (air drying) [5] [6] [13]-[15].

4) Bulk Density 
By definition, the apparent density of a compact is defined as the quotient of the dry weight of the finished product, the volume occupied by the solid material, including voids contained in the grains. Measuring a density following the determination of the percentage of water absorbed in a balance beam, and immersed in a beaker of distilled water [5] [6] [13]-[15].

5) Linear Shrinkage

Determining the value of shrinkage is by consideration of the variation of the average length of the recorded product between the drying at $105^{\circ} \mathrm{C}$ and baking at various temperatures lines [5] [6].

6) Resonance

The resonance of a baked product was observed by hitting with a metal bar. The emitted noise can be matte or metallic [5] [6].

7) Colour

Colour is one of the criteria used for the selection of raw materials ceramic. Clay that cook red or yellow can be used in pottery; mud bricks and tiles, as rich in iron oxide. Those who cook are less white and fuses can be used without adding in the production of refractory materials. Between these two extremes can be used in the production of stoneware and earthenware [5] [6] [13]-[15].

8) Strength

The compression test is used to determine an approximate compressive strength of the specimen well with an apparatus quarry reference measurement. Compression is done on a device called compress and its unit is the newton [5] [6].

\section{Results and Discussion}

\subsection{Analysis of Raw Products}

\subsubsection{Preliminary Tests}

Simple preliminary tests namely: the feel, smell, test hand washing, and the bottle test showed that: the sample KO1 has a silty texture of coarse massive structure of existing elements. KO1 is "coloured earth" that is to say, dark gray, friable consistency, compact wet with no organic matter. The test showed that the bottle of the inert aggregate proportion is sufficient [13]-[15]. The sample PI2 is itself of dark gray colour. Coarse elements are less abundant, with a slight presence of organic matter. The texture is sandy clay, massive structure of a compact consistency, hard brittle when dry. According to preliminary results the soil is used.

\subsubsection{Linear Drying Shrinkage}

The linear shrinkage on drying cylinder is obtained for the samples at each PI2 KO1 and percentage of additive in the mixture. Figure 2 shows the results of measurements of linear shrinkage during drying.

The linear drying shrinkage decreases with increasing of the adjuvant and is higher in the sample than KO1 sample PI2. The builder has a degreasing effect. The degreasing effect would be helped by the presence of quartz and mineral non-phyllitous.

\subsubsection{Particle Size Analysis}

Figure 3 and Figure 4 present the results of particle size analysis by sieving and sedimentometry clay materials Kongola and Pitoaré.

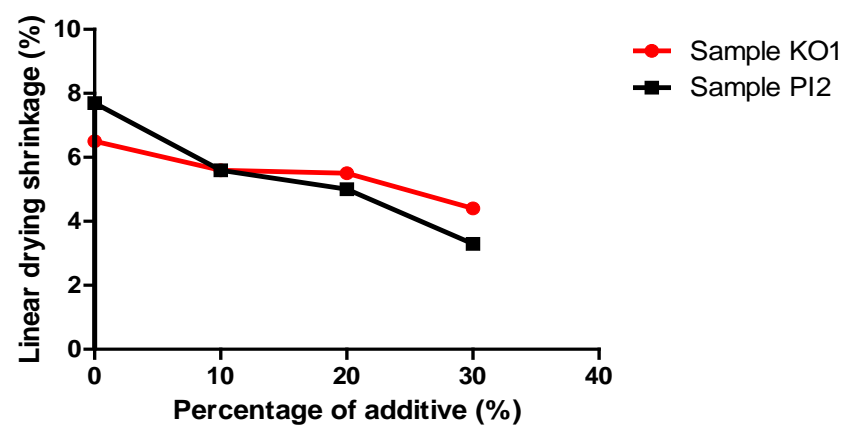

Figure 2. Outcome measures linear drying shrinkage. 


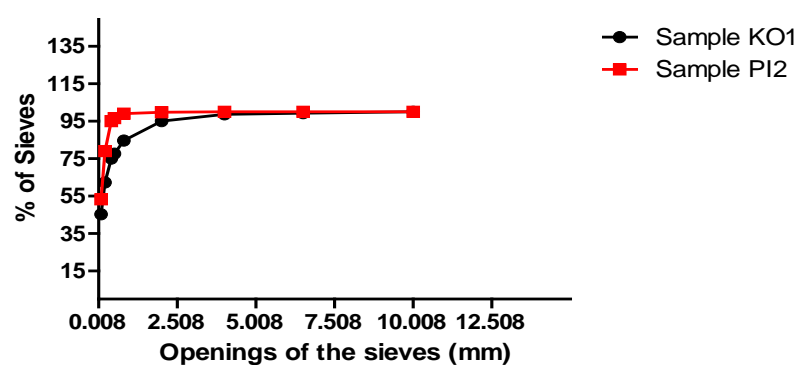

Figure 3. Results of particle size analysis by sieving.

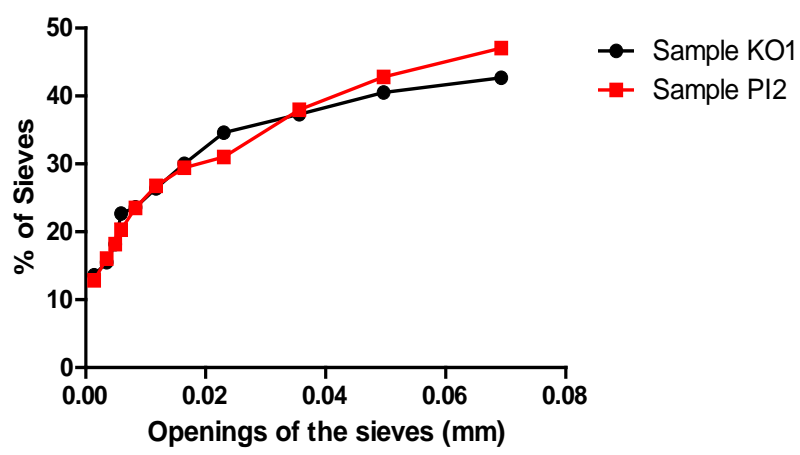

Figure 4. Results of particle size analysis by sedimentometry.

The particle size analysis shows that the material KO1 and PI2 material have almost the same clay and the same fractions silt fractions with a slight difference. The sample has large fraction KO1 gravel relative to PI2, while the sample has a large PI2 sand fraction versus KO1. Rates clay fraction are respectively 14 and 14.1. Rates sand fraction are 61.4 and 66.8 for KO1 sample PI2 leaving suggests that the sample has a KO1 plasticity index much greater than that of the sample PI2 [35]-[41].

\subsubsection{Atterberg Limits}

We have the values of liquidity limits as follows: 36.7 for KO1 and 23.5 for PI2. We also value obtained as the limits of plasticity 24.4 and 23.5 respectively for samples KO1 and IP2. Table 2 gives the results of the rheological analysis.

The values of the plasticity index are between 5 and 15, and then our samples are not plastics. The values obtained are in the range of plasticity indices used for tiles and tiles [42].

\subsubsection{Mineralogical Analysis}

The X-ray diffrractogrammes materials studied show the clay minerals, feldspathic minerals, oxides, hydroxides, phosphates, sulfates, and quartz. Table 3 shows the results of mineralogical analysis of clay materials.

\subsection{Analysis Curatives}

\subsubsection{Resonance}

Resonance gives a quick idea about the heat of a ceramic product. The intensity of the metal is proportional to the amount of glassy phase and mullite formed. Mullite is a stable inorganic high temperature, which provides the mechanical properties of material [19]. Our materials are reactive, and chemical reactions have taken place between $900^{\circ} \mathrm{C}-1000^{\circ} \mathrm{C}$. Samples of $0 \%, 10 \%, 20 \%, 30 \%$ gives a slight metallic sound to $900^{\circ} \mathrm{C}-1100^{\circ} \mathrm{C}$ [35][41].

\subsubsection{Colour}

The colour is determined by the presence of oxides of iron, titanium, and other impurities. The colour depends also on the condition of cooking; the oxidising atmosphere more or less, the maximum temperature [7]. Materials that do not belong to the domain cooked white clay when it has porosity greater than $6 \%$ and the field of 
Table 2. Results of the rheological analysis.

\begin{tabular}{cccc}
\hline Sample & Limits of liquidity & Limits of plasticity & Plasticity index \\
\hline KO1 & 36.7 & 24.4 & 12.3 \\
PI2 & 23.5 & 23.5 & 6.3 \\
\hline
\end{tabular}

Table 3. Results of mineralogical analysis of clay materials.

\begin{tabular}{|c|c|c|}
\hline \multirow[b]{2}{*}{ Minerals } & \multicolumn{2}{|c|}{ Distances ( $(\AA)$} \\
\hline & KO1 & PI2 \\
\hline Kaolinite & $7.15 ; 3.57 ; 2.38$ & $7.17 ; 3.58$ \\
\hline Ilménite & $2.74 ; 1.72 ; 2.54$ & $2.74 ; 2.52 ; 1.72$ \\
\hline Halloysite & 10.7 & 7.6; $10.7 ; 10$ \\
\hline Muscovite & $10 ; 5 ; 3.32$ & $10.1 ; 3.36 ; 5.04$ \\
\hline Biotite & $10.4 ; 3.32$ & $10.1 ; 3.37 ; 2.06$ \\
\hline Quartz & $3.34 ; 4.26 ; 1.82$ & $3.34 ; 4.26 ; 1.82$ \\
\hline Vermiculite & $14.4 ; 7.18 ; 4.79$ & $3.60 ; 4.79 ; 14.4 ; 7.18$ \\
\hline Chlorite & $14.3 ; 7.18 ; 4.79$ & \\
\hline Montmorillonite & $18 ; 9$ & $18 ; 9 ; 4.49$ \\
\hline Calcite & $3.04 ; 2.29 ; 1.80$ & $3.85 ; 3.03 ; 1.87$ \\
\hline Aragonite & $3.4 ; 1.98$ & / \\
\hline Anatase & $3.51 ; 1.89 ; 2.38$ & l \\
\hline Rutile & $3.26 ; 1.69 ; 2.49$ & $3.26 ; 1.69 ; 2.49$ \\
\hline Gypsum & 7.56; 3.06; 4.27 & $7.56 ; 3.06 ; 4.27$ \\
\hline Feldspath & $3.18 ; 3.24$ & l \\
\hline Amphibole & $8.40 ; 8.48$ & 8.40; 2.73; 3.16; 8.52; 3.1 \\
\hline Gibbsiste & $4.85 ; 4.37 ; 2.39$ & $4.85 ; 4.37 ; 2.39$ \\
\hline Geothite & $4.18 ; 2.46 ; 2.70$ & $4.85 ; 4.37 ; 2.39$ \\
\hline Hermatite & $2.69 ; 2.56 ; 1.69$ & $2.69 ; 2.56 ; 1.69$ \\
\hline
\end{tabular}

sandstone when the product is more dense [17]. And our baked at $900^{\circ} \mathrm{C}$ and $1000^{\circ} \mathrm{C}$ belong to terracotta and can be used for the manufacture of bricks land cotta pottery. While baked at $1100^{\circ} \mathrm{C}$ belong to cooked for percentages of $0 \%, 10 \%$ land and $20 \%$, whereas $30 \%$ we see already appear very dark colours. Very dark colour is that of sandstone [17] [35]-[41].

\subsubsection{Linear Firing Shrinkage}

When a material is subjected to heat occurs physicochemical transformations, these transformations from the water of hydration and the water content is removed, the polymorphic transformation of the quartz $\beta$ quartz and certain chemical reactions which lead to the formation of new mineral phases (mullite, ilmenite, tridymite). During these transformations there approximation particles, resulting in a decrease in length: linear shrinkage. The linear shrinkage is a translation of the reactivity of the material [11] [35]-[41]. Figures 5-7 present the linear shrinkage during cooking at $900^{\circ} \mathrm{C}, 1000^{\circ} \mathrm{C}$ and $1100^{\circ} \mathrm{C}$ respectively.

Temperatures in the $900^{\circ} \mathrm{C}$ to $1000^{\circ} \mathrm{C}$, the materials have low withdrawal and removal decreases as the percentage of feldspar in the mixture increases. At temperatures below $1100^{\circ} \mathrm{C}\left(<1100^{\circ} \mathrm{C}\right)$ remains inert quartz, clay 


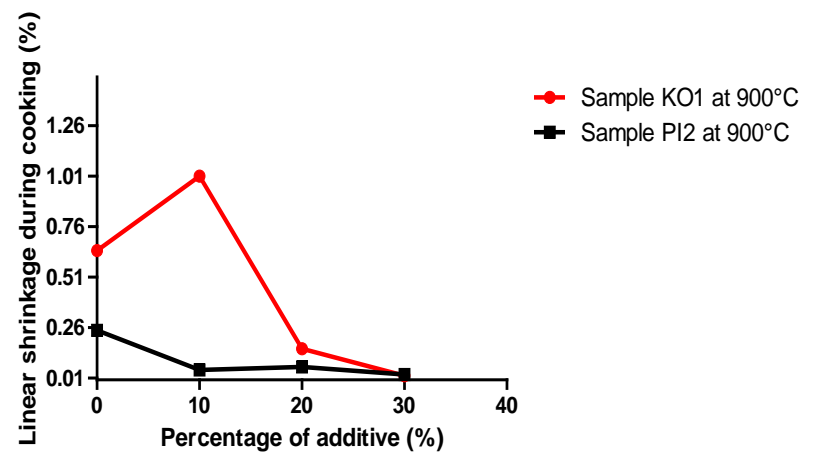

Figure 5. Linear shrinkage during cooking at $900^{\circ} \mathrm{C}$.

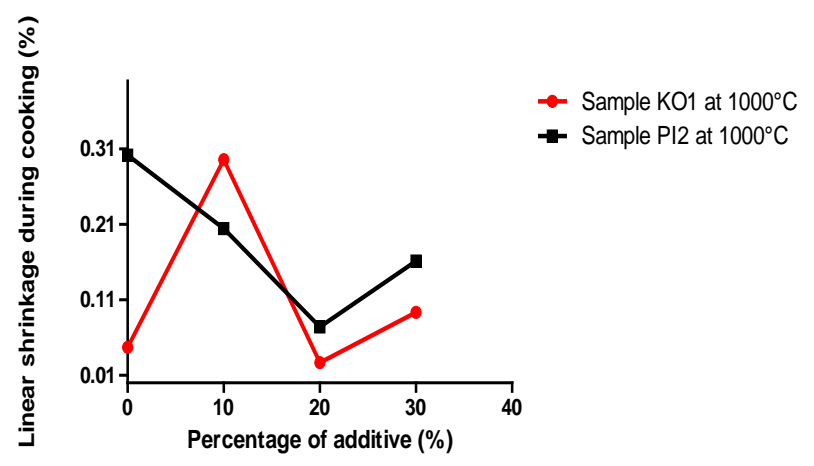

Figure 6. Linear shrinkage at firing to $1000^{\circ} \mathrm{C}$.

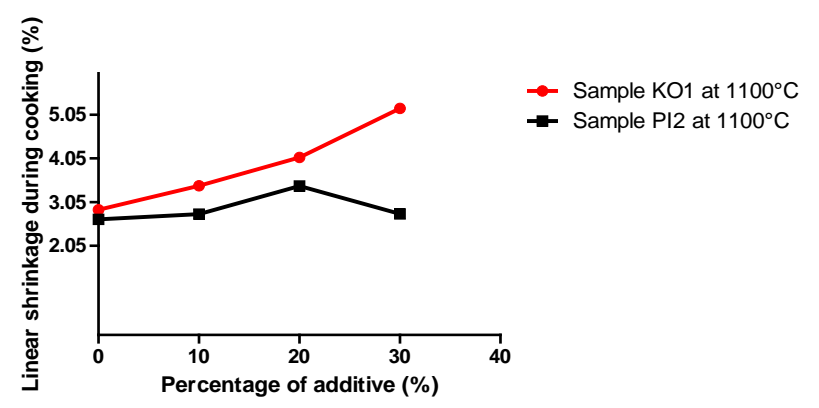

Figure 7. Linear shrinkage at firing to $1100^{\circ} \mathrm{C}$.

minerals and $1 / 1$ are also because their spaces are not inerfolières variables. At the temperature of $1100^{\circ} \mathrm{C}$ the shrinkage increased and a variation of 0.6 with the increase in average temperature. Is observed at temperatures below $1000^{\circ} \mathrm{C}$, the temperature has very little influence adjuvant. And at a temperature of $1100^{\circ} \mathrm{C}$ the temperature effect is noticeable, and removal increases significantly until the value of $5.19 \%$.

\subsubsection{Loss on Ignition}

The results show that the loss of ignition is in the range of temperature studied. The loss on ignition is an important feature to express the amount of organic matter present in the starting materials; it reflects the degree of vacuum and the percentage of water absorption. Dehydration reactions, the carbonation, combustion of organic matter, the decomposition of some minerals [33] [35]-[39] [41]. Figures 8-10 present the Lost in fire at 900 ${ }^{\circ}$, $1000^{\circ} \mathrm{C}$ and $1100^{\circ} \mathrm{C}$ respectively.

\subsubsection{Water Absorption}

Dehydrations reactions, the carbonation, combustion of organic matter, in certain minerals induce decomposition of the starting gas and water vapor which is interconnected pores appear to exist induce high absorption values water [11]. Figures $11-13$ present the Absorption coefficient of water at $900^{\circ} \mathrm{C}, 1000^{\circ} \mathrm{C}$ and $1100^{\circ} \mathrm{C}$ 


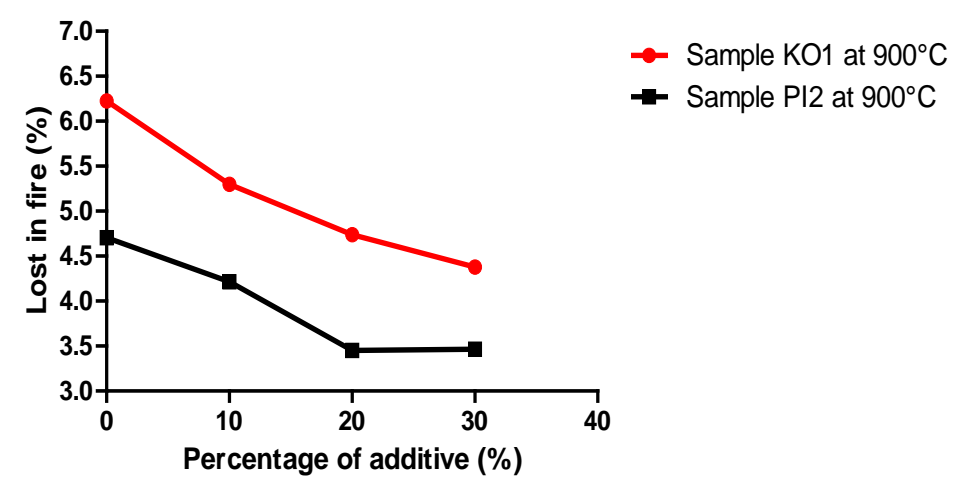

Figure 8. Lost in fire at $900^{\circ} \mathrm{C}$.

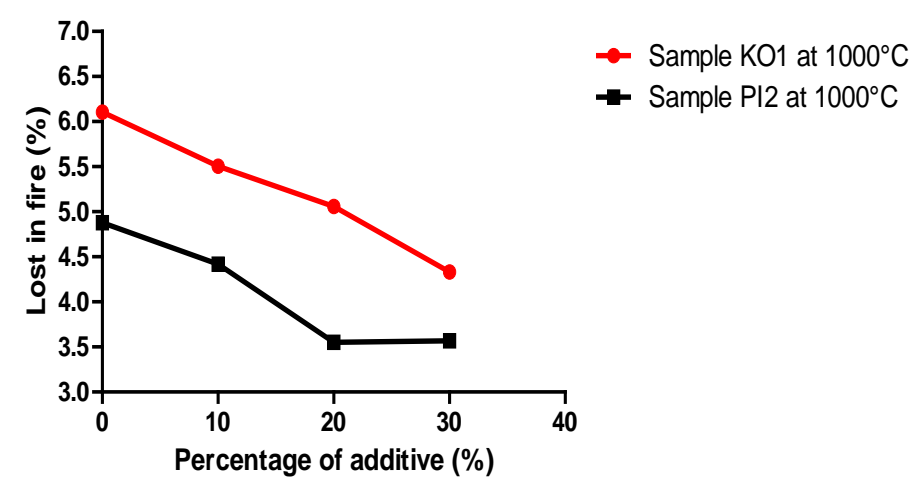

Figure 9. Lost in fire at $1000^{\circ} \mathrm{C}$.

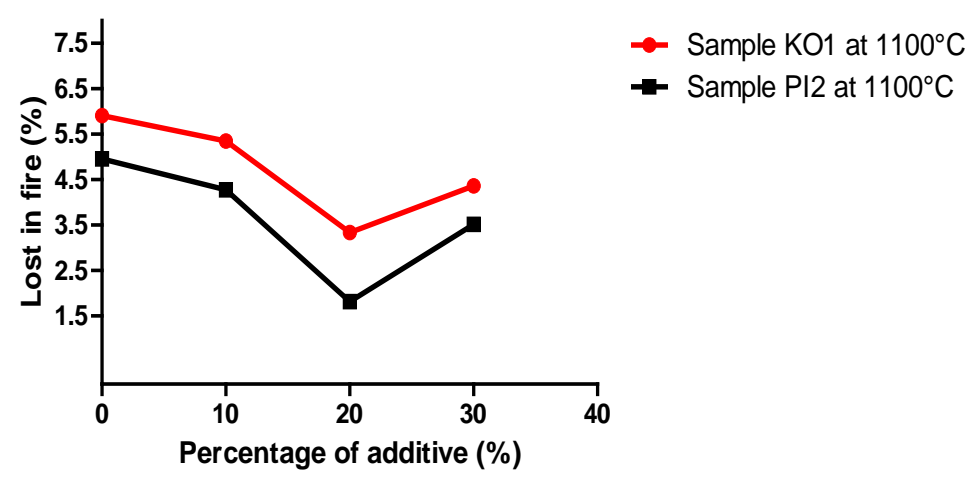

Figure 10. Lost in fire at $1100^{\circ} \mathrm{C}$.

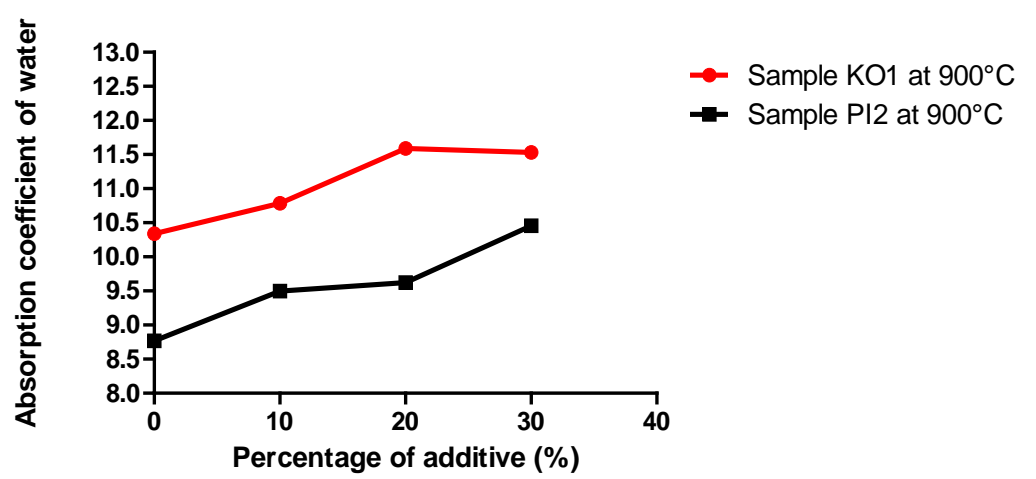

Figure 11. Absorption coefficient of water at $900^{\circ} \mathrm{C}$. 


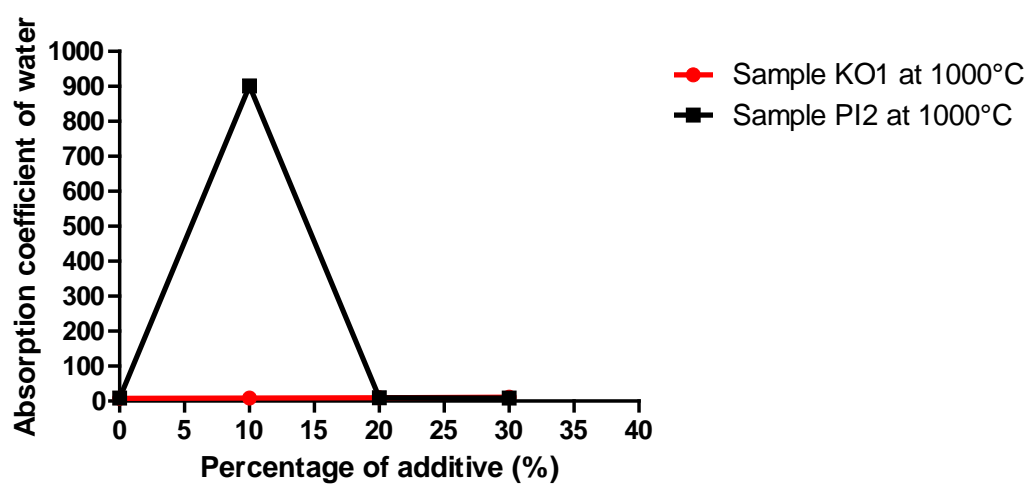

Figure 12. Absorption coefficient of water at $1000^{\circ} \mathrm{C}$.

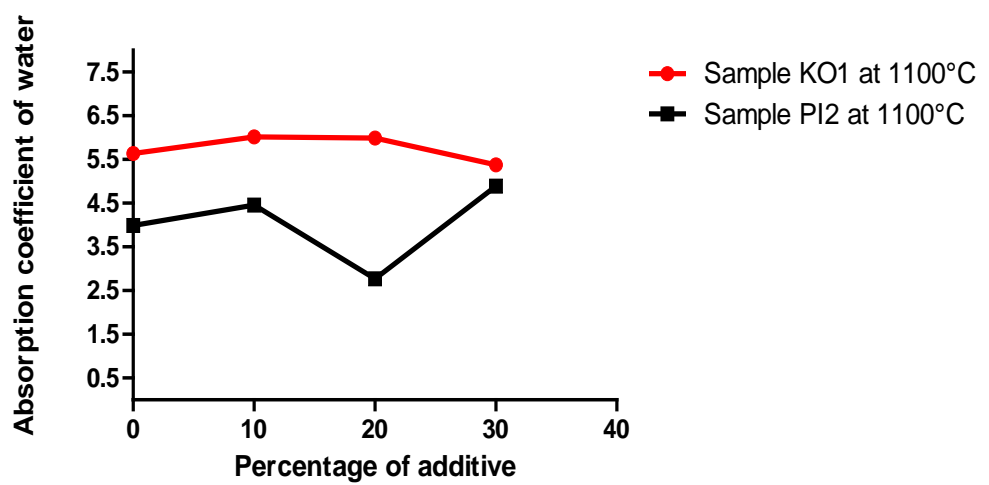

Figure 13. Absorption coefficient of water at $1100^{\circ} \mathrm{C}$.

respectively.

For our product, temperatures between $900^{\circ} \mathrm{C}, 1000^{\circ} \mathrm{C}$ and $1100^{\circ} \mathrm{C}$ the absorption decreases with increasing temperature and increase with increasing percentage of the mixture of feldspar. It is observed that below $1000^{\circ} \mathrm{C}$ the temperature remains stable adjuvant and begins to vitrify at temperatures of over $1000^{\circ} \mathrm{C}$.

\subsubsection{Bulk Density}

The increase in density is closely correlated to the linear shrinkage. An increase in density generally results in an increase of linear shrinkage and a decrease in the water absorption [12]. Figures 14-16 present the apparent mass volumique at $900^{\circ} \mathrm{C}, 1000^{\circ} \mathrm{C}$ and $1100^{\circ} \mathrm{C}$ respectively.

\subsubsection{Porosity}

The results show that the porosity of the product to temperature ranges of $900^{\circ} \mathrm{C}$ to $1000^{\circ} \mathrm{C}$ is still high. The sample values are higher $\mathrm{KO} 1900^{\circ} \mathrm{C}$ and $1000^{\circ} \mathrm{C}$ than those of sample PI2, and lower than $1100^{\circ} \mathrm{C}$. Figure 17 and Figure 18 present the percentage of porosity at $900^{\circ} \mathrm{C}$ and $1000^{\circ} \mathrm{C}$ respectively.

This shows that the vitrification of the sample is higher KO1 than PI2. These values are in the range of terracotta, they exceed $15 \%$. In this temperature range, the melt process ability of crystalline substances is not sufficient [25]-[28].

\subsubsection{Compressive Strength}

Resistance gives an idea of the quality of compaction and volume of voids in the material. The higher the value of the resistance of the sample, the higher the sample bears the stress before breaking. As the intensity of the bond between atom sample will be great with the evolution of resistance. In our case, the difference in resistance between the two samples is not large and is not noticeable at temperatures less $1000^{\circ} \mathrm{C}$. The KO1 sample has a slightly higher temperature of $1100^{\circ} \mathrm{C}$ values. $\mathrm{KO} 1$ specimens stabilised at $30 \%$ feldspars and fired at $1100^{\circ} \mathrm{C}$ show the highest resistance (23.84 MPa). This resistance is close to that of the concrete (25 MPa) [25]-[28]. Figure 19 and Figure 20 present the compression test at $1000^{\circ} \mathrm{C}$ and $1100^{\circ} \mathrm{C}$ respectively. 


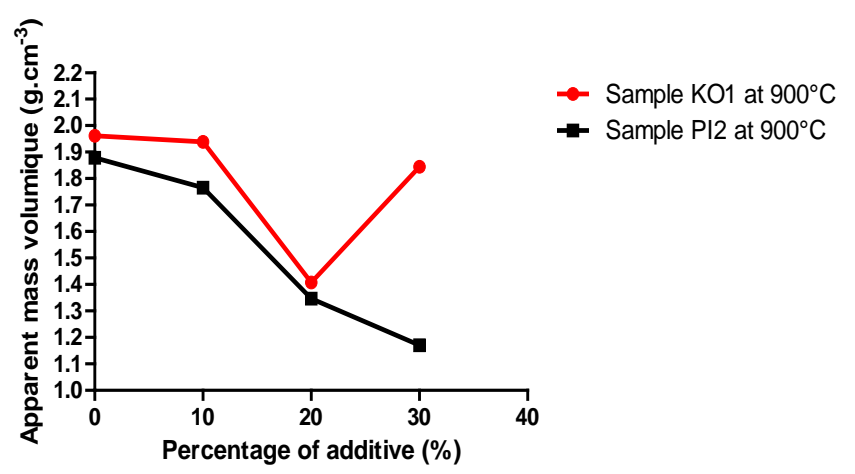

Figure 14. Apparent mass volumique at $900^{\circ} \mathrm{C}$.

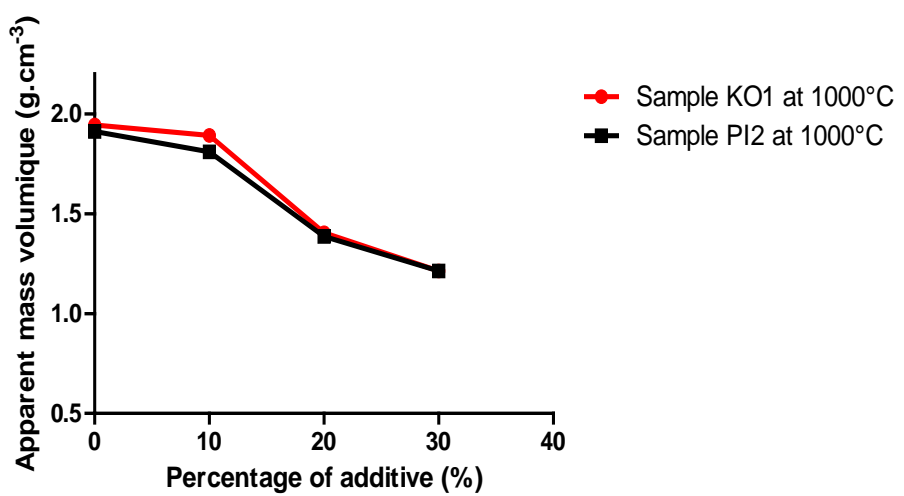

Figure 15. Apparent mass voluimique at $1000^{\circ} \mathrm{C}$.

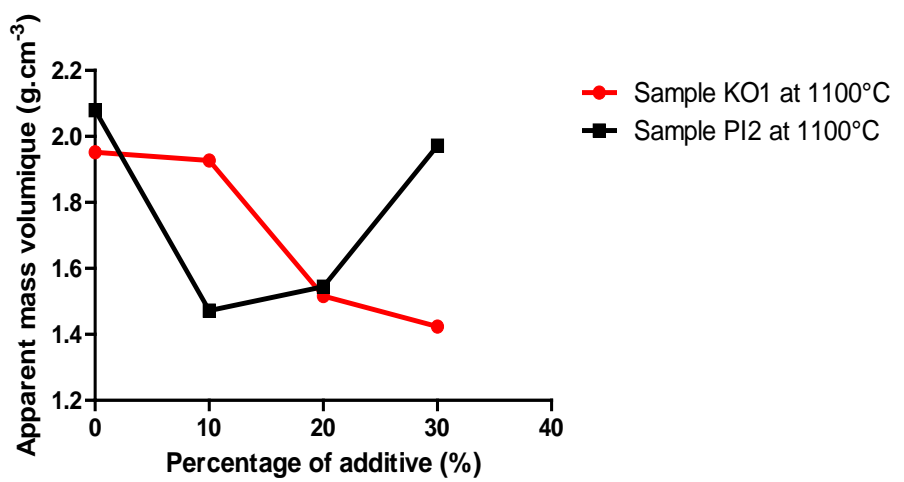

Figure 16. Apparent mass voluimique at $1100^{\circ} \mathrm{C}$.

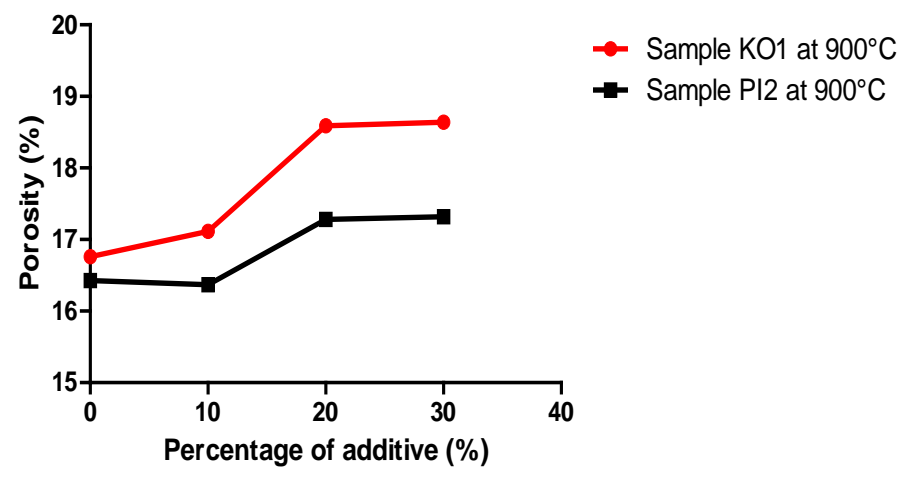

Figure 17. Percentage of porosity at $900^{\circ} \mathrm{C}$. 


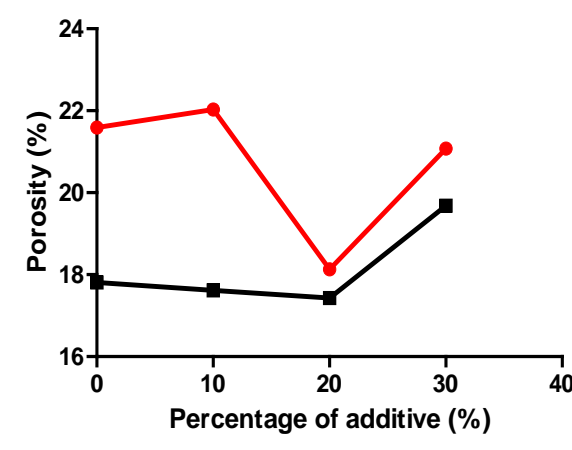

$\rightarrow$ Sample $\mathrm{KO} 1$ at $1000^{\circ} \mathrm{C}$

$\rightarrow$ Sample PI2 at $1000^{\circ} \mathrm{C}$

Figure 18. Percentage of porosity at $1000^{\circ} \mathrm{C}$.

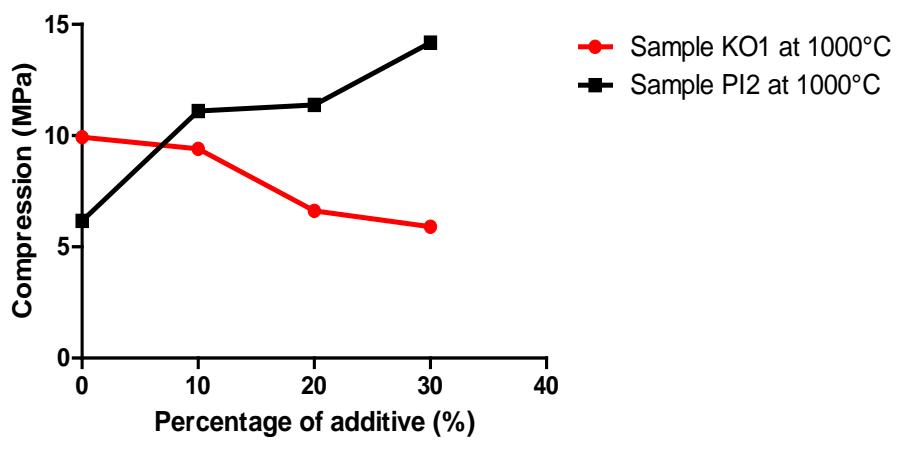

Figure 19. Compression test at $1000^{\circ} \mathrm{C}$.

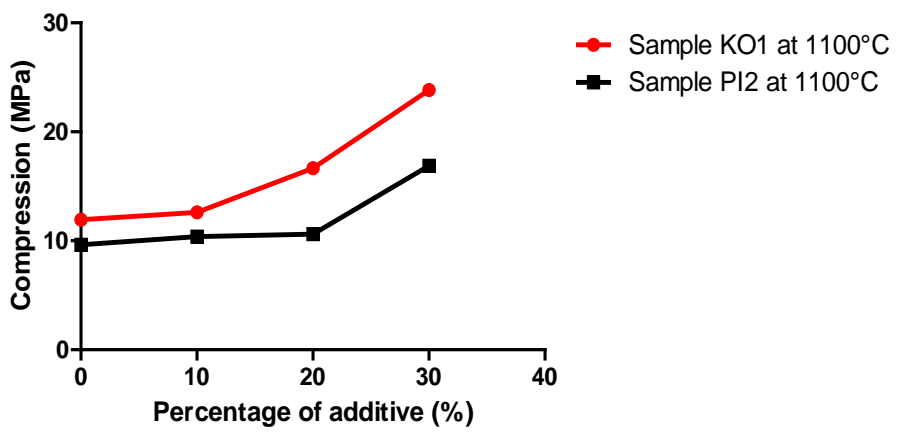

Figure 20. Compression test at $1100^{\circ} \mathrm{C}$.

\section{Conclusion and Outlook}

These results reveal the most suitable formula sample KO1 30\% feldspars at $1100^{\circ} \mathrm{C}$ firing temperature. However it is possible to incorporate silica powders in the material to improve its compressive strength.

Perspectives for further applications in industry are necessary to perform tests of formulation for glazing with the same feldspar or other used fluxes. In addition to having a clear idea of our cooking products, chemical analysis baking products will also be very important to clarify some results. It will also be important to conduct cooking tests between $1200^{\circ} \mathrm{C}-1400^{\circ} \mathrm{C}$ for different amounts of feldspar and appropriate mechanical analysis of these products, in order to discover other applications such as high-density stoneware.

\section{References}

[1] Nkoumbou, C., Villieras, F., Barres, O., Njopwouo, D. and Yvon, J. (2008) Physicochemical Properties of Talc Ore from Pout-Kelle and Memel Deposits (Central Cameroon). Clay Mineral, 43, 317. http://dx.doi.org/10.1180/claymin.2008.043.2.11

[2] Dondi, M., Ercolani, G., Melandri, C. and Mingazzini, C. (1999) The Chemical Composition of Porcelain Stoneware 
Tiles and Its Influence on Microstructural and Mechanical Properties. Interceram, 48, 75-83.

[3] Pialy, P., Nkoumbou, C., Villieras, F., Yvon, J. and Bonnet, J.-P. (2009) Characterization for Ceramic Applications of Clay Materials from Lembo Deposit, Mount Bana (Cameroon). Silicates Industriels, 74, 11-12.

[4] Moreira, J., Manhaes, J. and Holanda, J. (2007) Processing of Red Ceramic Using Ornamental. Elsevier, Amsterdam, 88-93.

[5] Nkoumbou, C., Njopwouo, D., Villiéras, F., Tchoua, F.M. and Yvon, J. (2006) Talc Indices from Boumnyebel (Central Cameroon), Physico-Chemical Characteristics and Geochemistry. Journal of African Earth Sciences, 45, 61-73. http://dx.doi.org/10.1016/j.jafrearsci.2006.01.007

[6] Njoya, D., Hajjaji, M., Nkoumbou, C., Elimbi, A., Kwekam, M., Njoya, A., Yvon, J. and Njopwouo, D. (2010) Chemical and Mineralogical Characterization and Ceramic Suitability of Raw Feldspathic Materials from Dschang (Cameroon). Bulletin of the Chemical Society of Ethiopia, 24, 39-46.

[7] NEMBOUE (2007) Cours de matériaux de construction. ENSP, Univ.de Yaoundé1, Yaoundé.

[8] Nkoumbou, C., Barbey, P., Yonta-Ngouné, C., Paquette, J.L. and Villiéras, F. (2014) Pre-Collisional Geodynamic Context of the Southern Margin of the Pan-African Fold Belt in Cameroon. Journal of African Earth Sciences, 99, 245260.

[9] Ghomari, F. (2012). Cours de science de matériaux de construction. Département de génie civil, fac.de science de l’ingénieur, Uni. d'Aboubekr Belkaid.

[10] Boch, P. (2001) Matériaux et processus céramiques. Edition BOCH. Hermès science publications, Paris, 283 p.

[11] Kamseu, E., Nzeukou, A., Lemougna, P., Billong, N., Melo, U.C. and Leonelli, C. (2013) Induration of Laterites in Tropical Areas: Assessment for Potential Structural Applications. Interceram, 6, 431-439.

[12] Bakop, T.T., Tene Fongang, R.T., Melo, U.C., Kamseu, E., Miselli, P. and Leonelli, C. (2013) Sintering Behaviors of Two Porcelainized Stoneware Compositions Using Pegmatite and Neheline Syenite Minerals. Journal of Thermal Analysis and Calorimetry, 114, 113-123.

[13] Bignozzi, M.C., Manzi, S., Lancellotti, I., Kamseu, E., Barbieri, L. and Leonelli, C. (2013) Mix-Design and Characterization of Alkali Activated Materials Based on Metakaolin and Ladle Slag. Applied Clay Science, 73, 78-85.

[14] Kamseu, E., Bakop, T., Djangang, C., Melo, U.C., Hanuskova, M. and Leonelli, C. (2013) Porcelain Stoneware with Pegmatite and Nepheline Syenite Solid Solutions: Pore Size Distribution and Descriptive Microstructure. Journal of the European Ceramic Society, 33, 2775-2784. http://dx.doi.org/10.1016/j.jeurceramsoc.2013.03.028

[15] Kamseu, E., Bignozzi, M.C., Melo, U.C., Leonelli, C. and Sglavo, V.M. (2013) Design of Inorganic Polymer Cements: Effects of Matrix Strengthening on Microstructure. Construction and Building Materials, 38, 1135-1145. http://dx.doi.org/10.1016/j.conbuildmat.2012.09.033

[16] Tamen, J., Nkoumbou, C., Reusser, E. and Tchoua, F. (2015) Petrology and Geochemistry of Mantle Xenoliths from the Kapsiki Plateau (Cameroon Volcanic Line): Implications for Lithospheric Upwelling. Journal of African Earth Sciences, 101, 119-134.

[17] Selim, D. (2005) Matériaux et revêtements céramiques multi fonctionnals par PECVD ET SPS pour l’intégration de puissance haute température haute-tension.

[18] Dejou, J. (2010) Les céramiques. Support de cours. Sociétés francophone des biomatériaux dentaires.

[19] Catauro, M., Bollino, F., Lancellotti, I., Kamseu, E. and Leonelli, C. (2010) Chemical and Biological Characterization of Geopolymers for Potential Application as Hard Tissue Prostheses. Advances in Science and Technology, 69, 192197.

[20] Romagnoli, M., Leonelli, C., Kamseu, E. and Gualtieri, M.L. (2012) Rheology of Geopolymer by DOE Approach. Construction and Building Materials, 36, 251-258. http://dx.doi.org/10.1016/j.conbuildmat.2012.04.122

[21] Catauro, M., Bollino, F., Kansal, I., Kamseu, E., Lancellotti, I. and Leonelli, C. (2012) Mechanical and Biological Characterization of Geopolymers for Potential Application as Biomaterials.

[22] Kamseu, E., Ceron, B., Tobias, F., Leonelli, E., Bignozzi, M.C., Muscio, A. and Libbra, A. (2012) Insulating Behavior of Metakaolin-Based Geopolymer Materials Assess with Heat Flux Meter and Laser Flash Techniques. Journal of Thermal Analysis and Calorimetry, 108, 1189-1199. http://dx.doi.org/10.1007/s10973-011-1798-9

[23] Kamseu, E., Nait-Ali, B., Bignozzi, M.C., Leonelli, C., Rossignol, S. and Smith, D.S. (2012) Bulk Composition and Microstructure Dependence of Effective Thermal Conductivity of Porous Inorganic Polymer Cements. Journal of the European Ceramic Society, 32, 1593-1603.

[24] Kamseu, E., Catania, V., Djangang, C., Sglavo, V.M. and Leonelli, C. (2012) Correlation between Microstructural Evolution and Mechanical Properties of $\alpha$-Quartz and Alumina Reinforced K-Geopolymers during High Temperature Treatments. Advances in Applied Ceramics, 111, 120-128. 
[25] Kamseu, E., Leonelli, C. and Obonyo, E. (2011) Evolution of Fired Clay Products: From Origin to Sustainable Building Ceramics. Interceram, 60, 221-225.

[26] Djanganga, C.N., Kamseu, E., Lecomte, G.L., Soro, J., Melo, U.C., Elimbi, A., Blanchart, P. and Njopwouo, D. (2011) Sintering Behavior of Porous Refractory Kaolin-Corundum Composites: Phase Evolution and Densification. Materials Science and Engineering: A, 528, 8311-8318. http://dx.doi.org/10.1016/j.msea.2011.07.006

[27] Obonyo, E., Kamseu, E., Melo, U.C. and Leonelli, C. (2011) Advancing the Use of Secondary Inputs in Geopolymer Binders for Sustainable Cementitious Composites: A Review. Sustainability, 3, 410-423.

[28] Kamseu, E., Leonelli, C., Chinje, U.M., Perera, D.S. and Leougna, P.N. (2011) Polysialate Matrixes from Al-Rich and Si-Rich Metakaolins: Polycondensation and Physico-Chemical Properties. Interceram, 60, 25-31.

[29] Lemougna, P.N., Chinje Melo, U.F., Kamseu, E. and Tchamba, A.B. (2011) Laterite Based Stabilized Products for Sustainable Building Applications in Tropical Countries: Review and Prospects for the Case of Cameroon. Sustainability, 3, 293-305.

[30] Billong, N., Melo, U.C., Kamseu, E., Kinuthia, J.M. and Njopwouo, D. (2011) Improving Hydraulic Properties of Lime-Rice Husk Ash (RHA) Binders with Metakaolin (MK). Construction and Building Materials, 25, $2157-2161$.

[31] Tippayasam, C., Boonsalee, S., Sajjavanich, S., Ponzoni, C., Kamseu, E. and Chaysuwan, D. (2010) Geopolymer Development by Powders of Metakaolin and Wastes in Thailand. Advances in Science and Technology, 69, 63-68.

[32] Kamseu, E., Rizzuti, A., Leonelli, C. and Pereran, D. (2010) Enhanced Thermal Stability in $\mathrm{K}_{2} \mathrm{O}-$ Metakaolin-Based Geopolymer Concretes by $\mathrm{Al}_{2} \mathrm{O}_{3}$ and $\mathrm{SiO}_{2}$ Fillers Addition. Journal of Materials Science, 45, 1715-1724.

[33] Kamseu, E., Leonelli, C., Boccaccini, D.N., Veronesi, P., Sglavo, V.M., Sglavo, V.M., Melo, U.C. and Jopwouo, D.N. (2009) Alkali-Silica Glassy Matrix (AGM) as Replacement for Feldspar in Conventional Porcelain Compositions. Silicates Industriels, 74, 131-138.

[34] Djangang, C.N., Kamseu, E., Elimbi, A., Lecomte, G.L. and Blanchart, P. (2014) Net-Shape Clay Ceramics with Glass Waste Additive. Materials Sciences and Applications, 5, 592-602.

[35] Kamseu, E., Braccini, S., Corradi, A. and Leonelli, C. (2009) Microstuctural Evolution during Thermal Treatment of Three Kaolinitic Clays from Cameroon. Advances in Applied Ceramics, 108, 338-346.

[36] Kamseu, E., Leonelli, C., Perera, D.N., Melo, U.C. and Lemougna, P.N. (2009) Investigation of Volcanic Ash Based Geopolymers as Potential Building Materials. Interceram, 58, 136-140.

[37] Leonelli, C., Kamseu, Melo, U.C., Corradi, A. and Pellacani, G.C. (2008) Mullitisation Behavior during Thermal Treatment of Three Kaolinitic Clays from Cameroon: Densification, Sintering Kinetic and Microstructure. Interceram, 57, 396-401.

[38] Lemougna, P.N., Balo Madi, A., Kamseu, E., Melo, U.C., Delplancke, M.P. and Rahier, H. (2014) Influence of the Processing Temperature on the Compressive Strength of Na Activated Lateritic Soil for Building Applications. Construction \& Building Materials, 65, 60-66. http://dx.doi.org/10.1016/j.conbuildmat.2014.04.100

[39] Kamseu, E., Rizzuti, A., Miselli, P., Veronesi, P. and Leonelli, C. (2009) Use of Noncontact Dilatometry for the Assessment of the Sintering Kinetics during Mullitization of Three Kaolinitic Clays from Cameroon. Journal of Thermal Analysis and Calorimetry, 98, 757-763. http://dx.doi.org/10.1007/s10973-009-0434-4

[40] Leonelli, C., Kamseu, E., Boccaccini, D.N., Sglavo, V.M. and Pellacani, G.C. (2009) Alkali-Ions Diffusion, Mullite Formation, and Crystals Dissolution during Sintering of Porcelain Bodies: Microstructural Approach. Journal of Materials: Design and Applications, 223, 183-191.

[41] Leonelli, C., Kamseu, E., Melo, U.C., Corradi, A. and Pellacani, G.C. (2009) Descriptive Microstructure and Fracture Surface Observations of Fired Volcanic Ash. Journal of Materials Science, 44, 4944-4952. http://dx.doi.org/10.1007/s10853-009-3755-6

[42] Tchamba, A.B., Melo, U.C., Lecomte-Nana, G.L., Kamseu, E., Gault, C., Yongue, R. and Njopwouo, D. (2014) Use of Bauxite from Cameroon for Solid State Sintering and Characterization of Calcium Dialuminate $\left(\mathrm{CaO}_{2} \mathrm{Al}_{2} \mathrm{O}_{3}\right)$ Refractory Cement. Ceramics International, 40, 1961-1970. http://dx.doi.org/10.1016/j.ceramint.2013.07.105 
Scientific Research Publishing (SCIRP) is one of the largest Open Access journal publishers. It is currently publishing more than 200 open access, online, peer-reviewed journals covering a wide range of academic disciplines. SCIRP serves the worldwide academic communities and contributes to the progress and application of science with its publication.

Other selected journals from SCIRP are listed as below. Submit your manuscript to us via either submit@scirp.org or Online Submission Portal.
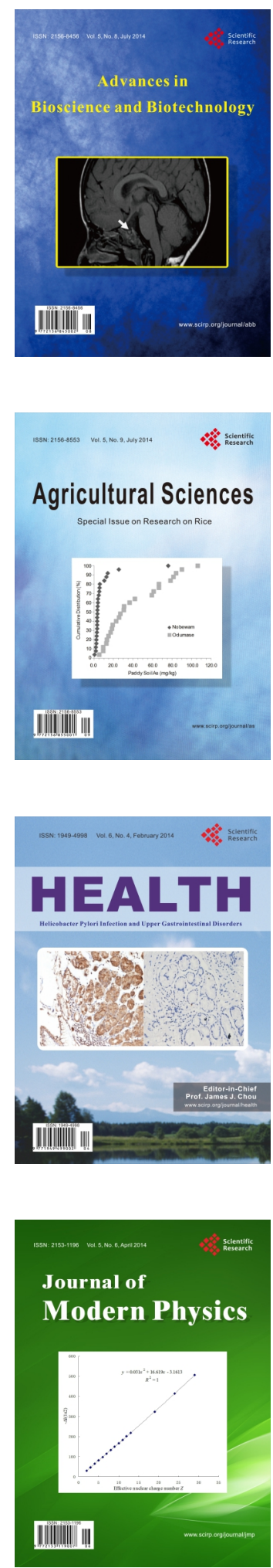
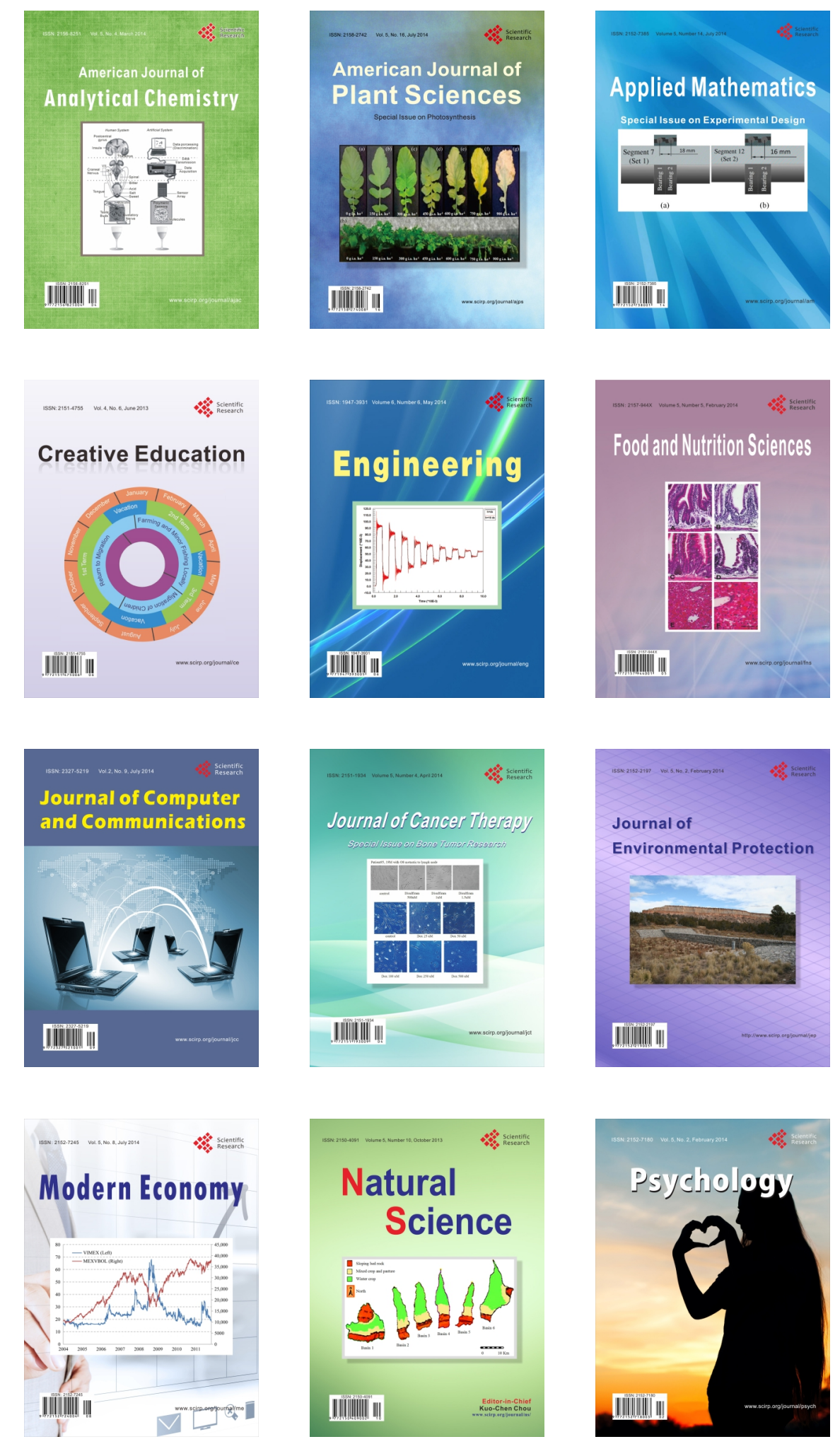